\title{
Behaviour of Households on Financial Investments Market
}

\author{
Bagautdinova N.PhD \\ Nayda A. PhD \\ Hayrullin B. PhD \\ Arzhantseva N. PhD
}

Doi:10.5901/mjss.2014.v5n12p103

\begin{abstract}
In the article the formation of social and economic policy of the region is investigated on the basis of the assessment of labor potential. The system of estimated indicators for testing decisions made within regional management for Pareto-optimality is created. The authors also offer an integrated indicator of the efficiency of social and economic policy of the region as the basic indicator of the evaluation of the decisions made for the implementation of social and economic policy of the region. They also create the mechanism of management of the region by means of implementation of social and economic policy on the basis of labor potential.
\end{abstract}

\section{Introduction}

In the conditions of postindustrial society the importance of financial sphere is growing rapidly. Alongside with the traditional function of effective redistribution of resources among the subjects of the real sector this sphere starts to perform an independent function, which is revealed in the usage of the immanent growth factors irrespectively of the conditions and lines of the development of other economic sectors. It finds its reflection in the formation of derivatives and the objects of infrastructure providing their effective usage. High yield of financial operations conditions the reallocation of sources in favour of the financial sector, which is reflected in high tempos of its growth. According to experts, a daily volume of transactions has increased from 1 bln dollars in the 1970s of the $20^{\text {th }}$ century up to 3-4 trn at present, with the volume of goods-and-services trade increasing by $50 \%$ only [1]. As the key factors in the increasing role of the financial sector in modern world economy there might be mentioned the changing of its structure leading to the replacement of the commercial credit by the derivatives as the source of income of its subjects, the priority of the short-term form of financing, excess of refinancing rates of the Central banks over the tempos of economic growth [2], which predestined the redistribution of resources in favour of speculative trading. [3]. As the countries balances of payments are deteriorating and the effective control over the conditions of the financial sector is not provided by the national governments, all this has brought to changes of the investment structure and singling out of two components in the financial sector, one of which is oriented to provide interaction between saving and investments, and the other - to increment the speculative capital.

The qualitative changes of relations in the financial sector of economy are caused by the transformational processes in the real sector, which is reflected in the growth of asset value and in the choice of more risky methods of their redistribution by the entrepreneurs [4]. At the same time the dynamics of the financial markets indicators doesn't reflect objectively the dynamics of the processes of production, which causes strengthening of volatility of external environment of business entities in the real sector of economics and taking ineffective management decisions. In these conditions the process of strategic planning gets seriously complicated and there arises the necessity for additional expenses on the risk assurances, the structure of which has seriously changed [5].

Alongside with the negative consequences for the real sector of economy, revealed in the growth of the cost of financial resources and the reduction of money access, the world recession has brought to the formation of new sources of development, among which there are some reduction in prices on the markets of production factors, which created the potential opportunity for the increase of investment expenditures, decrease of the debt burdens due to the bonds repurchase characterized by the relapse of the market value, etc. In the Russian Federation it takes the form of inefficiency of traditional branches of economy, which causes release of significant volume of labour and material resources, which might be used for building objects of infrastructure, technical retooling and modernization of existing process units and for creating new science-intensive industries, etc. [6]. In the circumstances of lowering of the 
attractiveness of the methods of debt financing and high expenditures of mobilization of resources via the capital market there arises the necessity to search for organizational and managerial innovations, the implementation of which strengthens the market power of particular business entities and provides the increase of their level of competition.

\section{The Method of Research: Adaptation of the Model Pocd}

The development of business entities in the conditions of turbulence of the consumer appeal of investments into the financial and real sectors of economy presupposes the necessity of formation of a frame, which allows to formulate the priority factors of providing competitiveness of the business entity, including mobilization of resources, in the long-term with due account of the necessity to satisfy the needs of private persons and legal bodies (owners of investment resources) formed by the consumer appeal. As the initial frame for the evaluation of the possibilities for the competitive development of a business entity there was chosen the POCD model (people-opportunity-context-deal) [7, 8], modified in the research in order to reveal the most essential features of entrepreneurial development in the financial and real sectors of economy (table. 1), which determine prioritized entrepreneurial opportunities in the atmosphere of globalization of economy.

Table 1: POCD-Model modified for the financial and real sectors of economy on the basis of prioritized entrepreneurial opportunities

\begin{tabular}{|c|c|c|c|}
\hline № & $\begin{array}{c}\text { Name of the element of the } \\
\text { POCD model }\end{array}$ & Financial sector & Real sector \\
\hline 1 & $\mathrm{P}$ - entrepreneur's team & $\begin{array}{c}\text { The prioritized competence structure of the team } \\
\text { includes the skills of risk minimization of the } \\
\text { placement of financial instruments while } \\
\text { providing an appropriate return level }\end{array}$ & $\begin{array}{c}\text { The prioritized structure of the team includes } \\
\text { knowledge and skills allowing to create products and } \\
\text { services in the innovations sector on the basis of } \\
\text { realization of the property units }\end{array}$ \\
\hline 2 & $\begin{array}{l}0 \text { - entrepreneurial possibility } \\
\text { in demand with the market }\end{array}$ & $\begin{array}{c}\text { The need of private persons and legal bodies to } \\
\text { place the temporarily available cash assets in the } \\
\text { form of highly liquid assets providing quick return } \\
\text { on capital employed }\end{array}$ & $\begin{array}{l}\text { The need of private persons and legal bodies to } \\
\text { place the temporarily available cash assets in the } \\
\text { form investments into the innovative-oriented } \\
\text { business projects providing steady income in the } \\
\text { strategic perspective }\end{array}$ \\
\hline 3 & $\begin{array}{c}\mathrm{C} \text { - unique competencies of } \\
\text { the business entity }\end{array}$ & $\begin{array}{c}\text { Forming of the portfolio of financial instruments } \\
\text { corresponding by the structure risk-economic } \\
\text { viability to the needs of private persons and legal } \\
\text { bodies having temporarily available cash assets }\end{array}$ & $\begin{array}{l}\text { Forming of the portfolio of competencies allowing to } \\
\text { implement innovative business projects, generating } \\
\text { the correlation risk-economic viability on the level not } \\
\text { lower than the market one. }\end{array}$ \\
\hline 4 & $\begin{array}{l}\mathrm{D}-\text { the possibility to } \\
\text { consummate transactions in } \\
\text { the line with the basic activity } \\
\text { of the business entity }\end{array}$ & $\begin{array}{c}\text { The correspondence of the current state and } \\
\text { prospects of the development of the business } \\
\text { company institutional environment to the current } \\
\text { configuration of the primary financial product } \\
\text { offered by the company }\end{array}$ & $\begin{array}{l}\text { The correspondence of the current state and } \\
\text { prospects of development of the business company } \\
\text { and the necessity of the business entity to use and } \\
\text { implement innovations on the basis of realization of } \\
\text { the objects of intellectual property }\end{array}$ \\
\hline
\end{tabular}

As is seen from the table, from the point of view of customer appeal the securing steady basis of a business entity in modern conditions presupposes either the necessity of its functioning and development within the framework of the financial sector, which will allow to provide the generation of the economic viability on the level not lower than $30 \%$ annualized gain on the invested capital, or the development in the framework of the real sector on the basis of the realization of fundamental and improving innovations. All this forms a possibility to generate the similar level of economic viability.

\section{The Assessment of Customer Value of a Financial Sector Product}

The carried-out analysis showed that the decision of households and economic agents where to place the temporarily available cash assets is taken by them not only under the influence of customer appeal of different variants of investments, but also with the account to the expected behavour of other potential investors [9, 10]. The given circumstance allows us to consider the dilemma of capital placement in accordance with the statements of the game theory characterizing the games with the mixed variants of strategies; in this case the expected usefulness of placement of temporarily available cash assets within the framework of financing of the most appealing economic spheres in the financial and real sectors of economy will the higher if a fewer number of players choose the similar strategy of market 
behaviour. Thus, the cumulative utility of the measures while choosing the strategy of market behavior for the owner $U_{i}$ (s) may be formalized in the following way:

1) $U_{i}(s)=\Sigma u_{i}(a) \sqcap s_{j}\left(a_{j}\right)$,

with $u_{i}(a)$ - integral utility of the realization of the marked strategy a bahaviour on the market of placement of investment resources by the $i$ owner of the resources, a util;

$s_{j}\left(a_{j}\right)$ - probability of achieving the desired result from the point of view of securing the appropriate level of economic viability while realizing variant $a$ of a chosen mixed strategy $s$, a share.

The determining of the type of the mixed strategy for the behavour of the investment resources owner while choosing the prioritized variant of placement of temporarily available cash assets as a form of investments into the financial or real economic sectors presupposes the necessity of the evaluation of a better reaction to the behavour of the other participants on the market; which in its turn conditions the necessity of leveling the possibilities to reach the equilibrium by Nash taking into account the possibility to realize different scenarios of investments into the financial and real sectors, which can be formalized in the following way:

2) $\left.\Sigma u_{1}\left(a^{f(r)}\right)_{1} a^{r(f)}\right)^{*}{ }^{r(f)} 2-r_{1}=U_{1}$,

with $u_{1}$ - the utility of the investment resources owner (player 1), choosing the customer appealing strategy for the placement of temporarily available cash assets, shown as $a^{f(r)}$ while choosing financial $-f$ or real $-r$ sectors of economy accordingly, under the condition that the other market participants (player 2) consider the strategy for investing into the instruments of financial market (business projects) as customer appealing $\left.\mathrm{a}^{r(t)}\right)_{2}$ (the handling of the content of which is similar to the one described above for player 1, util;

$s^{r(f)}$ - the probability of choosing the customer appealing strategy for investing into the instruments of financial market (business projects) by other market players, a share;

$r_{1}$ - potential losses after the actualization of this choice by the owner of the investment resources choosing the customer appealing strategy for investing temporarily available cash assets into the financial (business) sector of economy, , a util;

$U_{1}$ - maximum utility of the mixed strategy of player 1 - the owner of the investment resources choosing the customer appealing strategy for investing temporarily available cash assets, achieved in the state of equilibrium by Nash, a util.

A similar approach is used to evaluate the utility of the actualization of the customer appealing strategy for investing temporarily available cash assets into the financial (business) sector of economy by player 2 (other market players). Equating of the gained value of utility allows us to calculate the prioritized probabilities of choosing different variants of the actualization of the strategy of placement of investment resources for achieving the Nash-equilibrium state by the owner.

Determining the tendencies of the development of business activity with the account to the prioritized choice made by households and business entities of the prioritized mixed strategies of the placement of temporarily spare financial assets [11] carried out in the research, was based on the statistic analysis of the investment attractiveness depending on the norm of economic viability on invested capital expected by the owners of investment resources. The carried-out analysis revealed the presence of a strong and direct dependence between a share of temporarily available cash assets owned by households and business entities and the level of the expected cost effectiveness of the invested capital (the correlation coefficient making $+0,7612$ ), which testifies about the rise of customer appeal of the investement projects of the real sector of economy with the increase of the share of the released capital.

Thus, the increase of available cash assets conditions the increase of investments into the entrepreneurs sector, marked by high risk level conditioned by the usage of fundamental innovations.

\section{Results and Recommendations}

The world crisis of 2008 and the following recession conclusively demonstrated the effect of objective laws of cyclic economic development expressed in the unstable dynamics of main macroeconomic indicators of some countries and their integrated entities.

A long history of repetitive rotation of increasing and decreasing trends of development show that forms of implementation of crisis phenomena are constantly changing, despite preserving a set of features attributed to them. A peculiar feature of the world crisis of 2008 is its large scale influence on the state of a vast majority of modern countries and population living on their territories, which is greatly caused by the changing nature of interrelations of the real and financial economic sectors with the increasing role of the latter.

In the set conditions while evaluating the trend of consumption behavior of households it is necessary to take into 
account the dependence of prioritized choice of projects in the financial and real economic sectors on the share of temporarily available cash assets of households and economic entities in the process of formation of the package of financial products.

\section{References}

Park A., Sabourian H. Herding and contrarian behavior in financial markets. Econometrica, Vol. 79, No. 4, July, 2011, pp. 973-1026.

Ajupov A. Definitions of concepts scope and interaction of risk-engineering on the financial market. Life Science Journal 2014; 11(6s): 337-340.

Fakhrutdinova, E., Safina, L., Kolesnikova, J., Fedor, Mikhailov. Quality formation of working life of the youth// World Applied Sciences Journal. Volume 27, Issue 13, 2013, Pages 87-91.

Preis T., Schneider J., Stanley H.E. Switching processes in financial market. Proceedings of the National Academy of Sciences of the United States of America, Vol. 108, No. 19 (May 10, 2011), pp. 7674-7678.

Glebova I.S., Rodnyansky D., Sadyrtdinov R., Khabibrakhmanova R. and Yasnitskaya Y. Evaluation of Corporate Social Responsibility of Russian Companies Based on Nonfinancial Reportingll Middle-East Journal of Scientific Research 13 (Socio-Economic Sciences and Humanities): 143-148, 2013.

Kundakchyan R.M., Zulfakarova L.F. Current issues of optimal capital structure based on forecasting financial performance of the company. Life Science Journal 2014; 11(6s): 368-371.

Moss T., Gras D. A Review and Assessment of Social Entrepreneurship Textbooks. Academy of management learning education, September 2012 11:pp. 518-527.

Kirshin I.A., Datsyk A.A., Titov A.V. Forecasting the Dynamics of an Innovative Cycle. - World Applied Sciences Journal (Economics, Management and Finance). - 2013. - №27. - P. 197 - 201.

Glebova I.S., Sadyrtdinov R. and Rodnyansky D. Impact Analysis of Investment Attractiveness of the Republic of Tatarstan on Fixed Investments of its Leading Companies // World Applied Sciences Journal 26 (7): 911-916, 2013.

Verhoef P., Franses P., Donkers B. Changing perceptions and changing behavior in customer relationships. Marketing Letters, Vol. 13, No. 2 (May, 2002), pp. 121-134.

Ross S. Institutional marketing, financial markets and financial innovation. The Journal of Finance, Vol. 44, No. 3, Papers and Proceedings of the Forty-Eighth Annual Meeting of the American Finance Association, New York, New York, December 28-30, 1988 (Jul., 1989), pp. 541-556.

Acs Z., Szerb L. Entrepreneurship, economic growth and public policy. Small Business Economics, Vol. 28, No. 2/3, March, 2007, pp. 109-122. 